\title{
The role of extrathecal tissue in the construction and functioning of some Ordovician and Silurian retiolitid graptoloids
}

\author{
DENIS EDWIN BEECHING BATES AND NANCY HARTSHORNE KIRK
}

Bates, D.E.B. \& Kirk, N. H.: The role of extrathecal tissue in the construction and functioning of some Ordovician and Silurian retiolitid graptoloids. Bull. geol. Soc. Denmark, vol. 35, pp. 85-102, Copen-hagen, July 1st, 1987. https://doi.org/10.37570/bgsd-1986-35-10

\begin{abstract}
Spinose and laciniate Ordovician graptoloids are briefly described and an attempt is made to explain the formation and anastomosis of their spines by secretion by cells within the mesenchyme of an extrathecal mantle. It is suggested that in Pipiograptus hesperus and Phormograptus sooneri the ciliated epidermis covering the expanded mesenchyme resulted in a smooth ciliary flow of water over the rhabdosome, the food particles being diverted to the zooids along ciliated funnels. In both of these taxa the thecal walls were largely unbandaged, the support and protection of the zooids being taken over by the mantled lacinia.

The umbrella-like ancora of certain non-retiolitid Silurian graptoloids is attributed to secretion beneath an extension of the mantle covering the virgella. Its development early in the growth of the metasicula seems only explicable if the ancora functioned as a food gathering organ while the young colony was still attached to the sea floor. In the Silurian retiolitids the ancora umbrella has extended back over the thecate part of the rhabdosome, taking over the support of the largely unbandaged thecae. Covered and lined with ciliated epidermis the ancora sleeve would have contributed to the ciliary flow, directing the efferent currents, sometimes from specialized stomata, but more usually from the distal trailing end of the rhabdosome giving optimum separation from the afferent currents to the thecal apertures, as well as a maximum contribution to the feeding rise.
\end{abstract}

D. E. B. Bates \& N. H. Kirk, Geology Department, University College of Wales, Aberystwyth, Dyfed SY23 $3 Q Q$, U.K., October 21st, 1986.

\section{Introduction}

The inward facing, evenly spaced autothecae of benthonic forms of Dictyonema suggest that the zooids were lophophorate, drawing coordinated ciliary currents down into the cone and passing the efferent currents out through the spaces between stipes and dissepiments (Kirk 1969).

Such ciliary action is most effective when the animal is stationary in relatively calm water, (and the regular conical form of Dictyonema suggests that it lived under such conditions), the ciliary current supplying the colony with both oxygen and particulate food. After the detachment of the colony in a nema-bearing form such as Dictyonema flabelliforme the situation was probably not at first radically altered, the relatively heavy cone, with the same orientation and sometimes stabilized by three vertical vanes, would have risen only slowly as a reaction to active nocturnal feeding, sinking back slowly by day.
A consideration of the micro- and ultra-structural details of graptolite periderm has led to the supposition (Kirk 1972, 1974, 1975) that it was secreted by epithelium covering the interconnected zooids filling the thecae and common canal, and by its continuation which lined the mantle evaginated at the "shoulder" of each zooid. Extension of the periderm by fusellar increments would have occurred in the "armpit" of each evagination where the secretory epithelium proliferated. Secretion of cortical bandages over the fusellar increments was evidently the result of the more or less delayed action of the same cells (Bates \& Kirk 1985).

The all-enveloping mantle of extrathecal tissue probably had a ciliated epidermis (Urbanek, Koren \& Mierzejewski 1982), its ciliary action augmenting that of the zooidal lophophores, and also helping to keep the surface of the colony clean. Gaseous exchange could have occurred through this epidermis, the large surface area of the graptolite colony being advantageous for res- 
piration as well as for suspension and for food collecting by ciliary action.

Between the lining of secretory epithelium and the ciliated mantle epidermis we postulate the existence of a mesenchyme of, perhaps, somewhat fluid intercellular matrix populated by rather mobile cells, a kind of mesogloea (Bates \& Kirk 1984). Within this mesenchyme there must have occurred metabolic exchange for secretion of the periderm, and there may also have been an abundance of low density inclusions, possibly of oil, or perhaps of solutions in which ammonium substituted for metallic ions as in cephalopods.

The resilient periderm of graptolites appears to have been constructed of a strongly bonded or cross-linked form of collagen (Towe \& Urbanek 1972; Crowther 1981), a substance with a density of about 1.3. It therefore seems unlikely that the small pterobranch-type zooids, connected only by stolons, as postulated by Crowther, could have maintained the heavy graptolite rhabdosome in suspension. But graptolite zooids completely filling the thecae and common canal, and enveloping the peridermal structures in an extra- thecal mantle, as outlined above, might have been able to do so if their ciliary activity had been accompanied by the buoyant effect of an abundance of lighter-than-sea-water inclusions within their more voluminous soft tissues.

During the early evolution of the graptoloids, reduction in the number of stipes, and change of their inclination to horizontal, may have resulted in more efficient food gathering without essentially altering the balance between heavy periderm and buoyant soft tissue. But with the change to reclined and scandent rhabdosomes, the compact construction, particularly of the very young rhabdosomes, may have upset this balance, reducing the surface area of the mantle relative to the weight of the peridermal framework. It may be for this reason that long spines are frequently found on the sicula and earliest thecae of dicellograptids, on the biserial parts of dicranograptids, and on some or all of the thecae of biserial graptoloids. In the uniserial graptoloids, which we suppose to have been usually more actively and spirally moving, pronounced spinosity is less frequent, though it occurs in
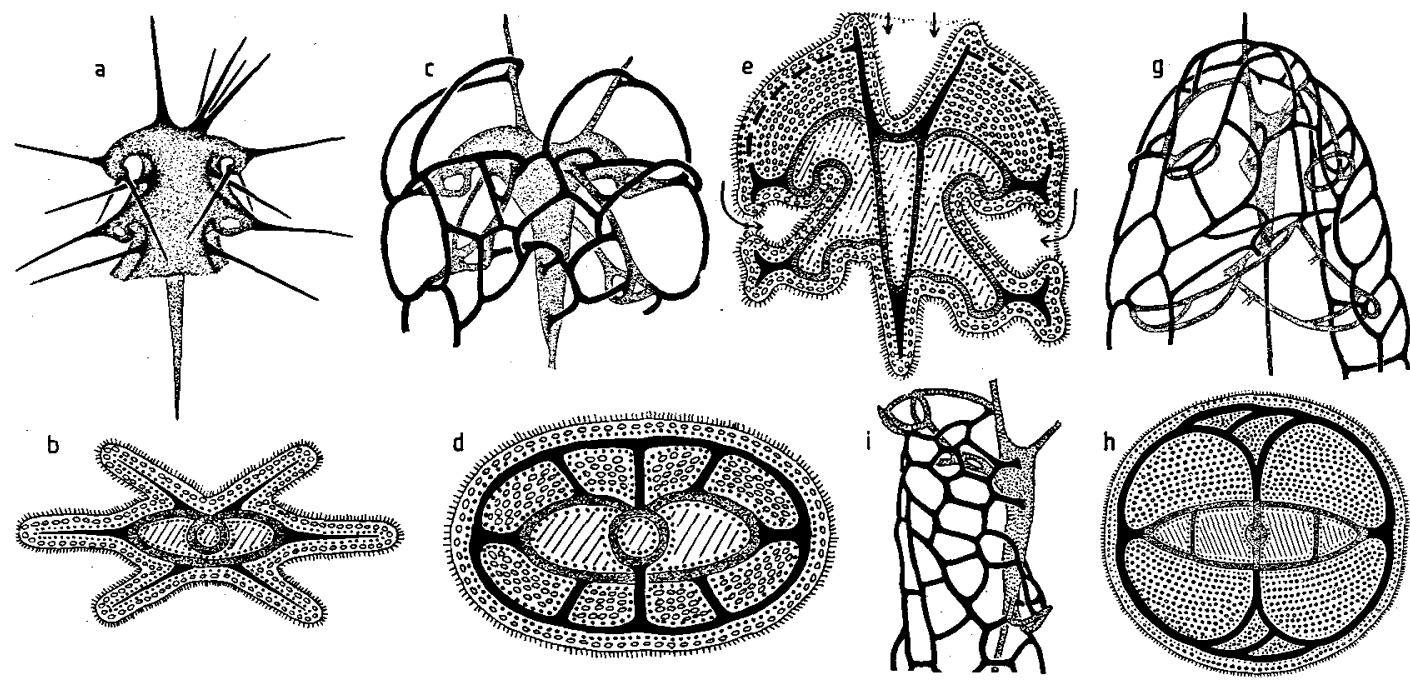

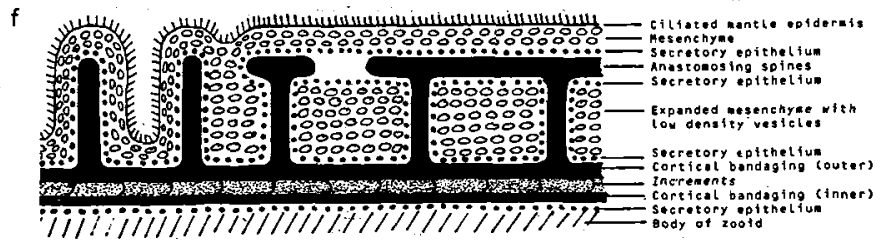

Fig. 1. Ordovician spined and laciniate graptoloids. See text for explanation. 
such compact forms as Monograptus leintwardinensis. Its function of increasing surface area and retarding sinking seems to have been taken over by thecal isolation and elongation in such forms as Rastrites which may also have returned to a relatively immobile suspension.

We shall now examine, in terms of the foregoing hypothesis, the role of extrathecal tissue in the construction and functioning of two morphological series of biserial, mainly retiolitid graptoloids.

1. A morphological series of Ordovician spinose and laciniate graptoloids (fig. 1)

Taking, as our point of departure the non-laciniate Ordovician graptoloid Dicaulograptus (fig. 1a) we find extreme spinosity associated with reduced corticization of the thecal walls (Bulman 1932). Concentration of cortical bandages along the sides of the otherwise almost uncorticized ventral walls, and around the edges of the introverted thecal apertures, is accompanied by the development of spines from the resulting ventral and apertural thickenings or "lists", and also from the sicular aperture. There appears to be no anastomosis between the spines, and we attribute their formation to local proliferation of the secretory epithelium lining the mantle, and to localized secretion beneath it (fig. 1b).

The association of exaggerated spinosity with weak corticization of the thecal walls suggests a device to increase surface area and buoyancy and decrease mobility, allowing strong lateral ciliary currents to be developed at the expense of the downward current which would otherwise have been required to counteract sinking. The increased surface area of the mantle would also have increased the capacity for gaseous exchange, and could have been an adaptation to life in oxygen-poor waters.

Although no close relationship is necessarily implied, the retiolitid Pipiograptus hesperus (Whittington 1955) has somewhat similar introverted thecae with walls so thin that they are only preserved as ragged fringes along the dorsal, ventral and apertural lists (fig. 1c; fig. 2). Again spines arise from the corticized sicular and thecal apertures, but those from the ventral lists are more numerous than in Dicaulograptus, and there are also spines from the obverse and reverse faces of the sicula and crossing canal.
Although in $P$. hesperus (fig. 2a) the spines seem to have been at first fine and tapering as in Dicaulograptus, they branch and subsequently anastomose to form a network or lacinia (fig. $2 b$ ). This seems to have had the form of a somewhat flattened cylinder and was probably domeshaped over the proximal end though we have no specimens sufficiently undamaged to show this (figs. 1d-e).

However, in spite of the imperfect preservation of the lacinia, it is possible to recognize a certain order in which the connections of the network were made. Thus we find that the subapertural spines of th $1^{1}$ and th $1^{2}$ sent branches proximally which anastomosed with branches from the sicular spines. Their median branches joined a spine arising from the th $1^{1}$-th $1^{2}$ crossing canal, and a corresponding spine arising from the obverse face of the sicula, while the distal branches from the subapertural spines of th $1^{1}$ and th $1^{2}$ joined proximal branches from those of th $2^{1}$ and th2 $2^{2}$.

Across the reverse and obverse faces of the rhabdosome the more distal spines arising from the ventral lists of th $2^{1}$ connected with the more proximal spines on the ventral lists of th2 $2^{2}$. And while the spines from the sides of the aperture of th2 ${ }^{1}$ joined lateral spines arising from the prosicular rim, those from the corresponding positions on th $2^{2}$ connected with spines arising just proximal to the prosicular apex.

Lists with a more proximal-distal (longitudinal) orientation connected the more "latitudinal" lists to form the network or lacinia. This seems to vary somewhat in detail, though within a basic pattern of construction which appears to be related to the order in which the thecae were secreted.

In some young specimens of $P$. hesperus the lacinia seems to be represented by tapering spines like those of Dicaulograptus. For such spines to branch and anastomose it seems necessary to postulate the expansion of the mesenchyme between the secretory epithelium lining the mantle and the ciliated epidermis covering it (fig. 1f). Within the expanded intercellular matrix of this mesenchyme we suppose the secretory cells to have proliferated and migrated leading to the formation of anastomosing tubes in which the lacinial network could have been secreted. Such proliferation and migration of secretory cells cer- 

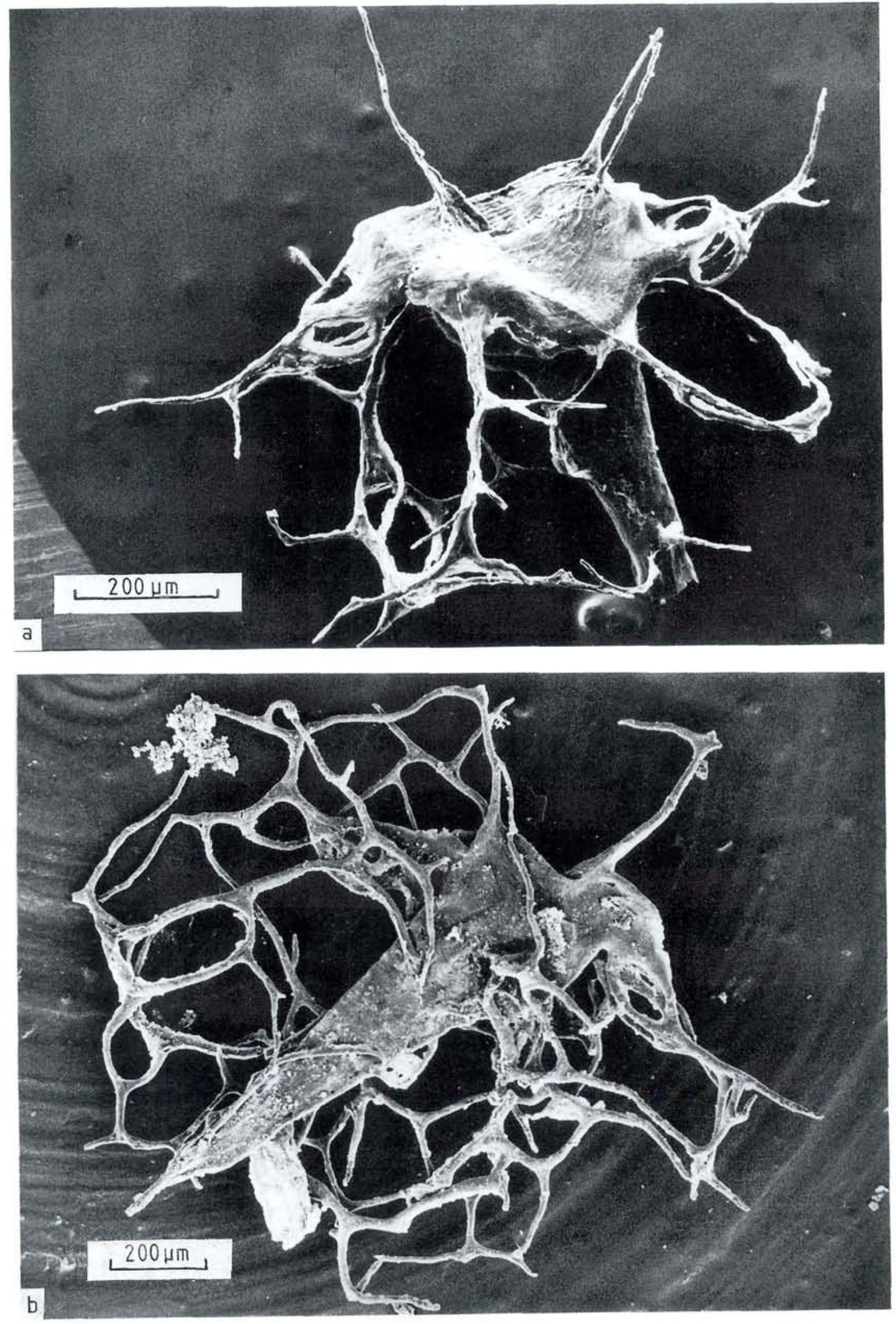

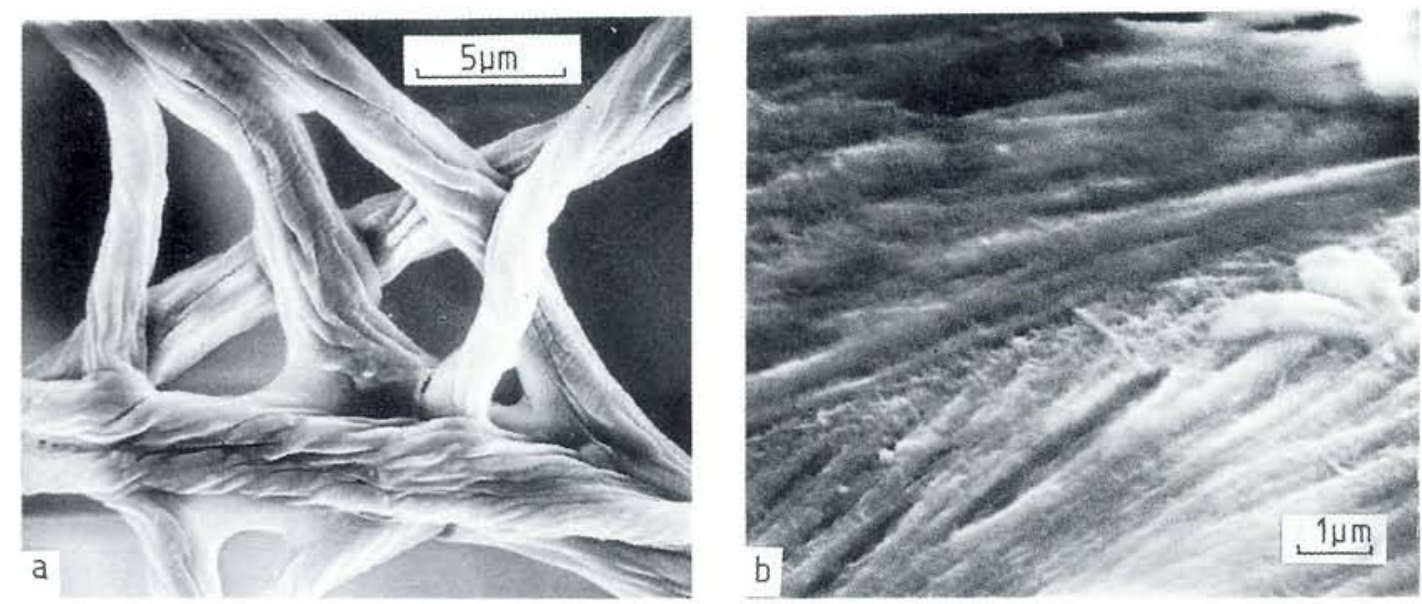

Fig. 3. Portion of network of recent horny sponge colony, formed of bundles of spongin fibrils, with close-up showing unconformities between successive arrays of superficial parallel fibrils (compare with graptolite bandaging). U.C.W. Stub 37. Negs. 85/20/22,25.

tainly occurs within the intercellular matrix of the mesenchyme in horny sponges (Vacelet 1971, Garrone 1978), and the anastomosing networks of fibres formed of fibrils of spongin (a form of collagen) which they secrete (fig. 3) are remarkably similar to the lacinial networks of Ordovician retiolitids. In the Demospongiae the directing of the spongin secretion seems to be partly controlled by non-skeletal fibrillar material in the intercellular matrix, but ultimately the control is by the genetic instructions carried by the secretory cells themselves. There are no zooids in sponges which could have painted or mortared the anastomosing networks by means of mobile preoral lobes (as suggested by Crowther (1981: 30) for the graptolites).

So we postulate a thick mesenchyme with secretory cells laying down a lacinial network in its outer part, just below the ciliated epiermis.

What might have been the significance of this evolutionary innovation?

In some of our immature specimens of $P$. hesperus the first cross connections appear to have extended from the sides of the apertural rim of th $2^{1}$ to the spines arising from the obverse and reverse faces of the prosicular rim. Such cross connections would have helped to support the introverted th $2^{1}$ whose walls are too thin to be preserved except as ragged fringes along the ventral, dorsal and apertural lists.
But while the lacinial network was probably important in the support of th $2^{1}$ and $2^{2}$, the thick mesenchyme which underlay it, and perhaps contributed to that support, probably had a significant buoyant effect too. Of low density in itself, it might also have contained an abundance of inclusions of less-than-sea-water density, giving it a net buoyancy. It is noticeable that the mesenchyme seems to have been particularly thick at the proximal end of the rhabdosome where its buoyancy could have balanced the weight of the thick corticized walls of the sicula and th $1^{1}$ and $1^{2}$.

Finally, it is necessary to recall that the epidermis over the lacinia-supported mesenchyme was probably ciliated, and that this ciliated epidermis would have lined deep and wide funnels leading to the sicular and thecal apertures (fig. 1e). In contrast to Dicaulograptus where spinosity may have resulted in near immobility, the ciliary activity in $P$. hesperus probably resulted in a smooth flow of water over the expanded colony, and a reciprocal feeding rise with minimal risk of entanglement with other rhabdosomes. Food particles, possibly caught in mucus, would have been swept into the ciliated funnels leading to the zooids. Whether these retained lophophores as conventionally imagined, or whether the funnels replaced them, it is impossible to decide. The flow of water over the mantle epidermis, and the expanded mesenchyme underlying it, would also

Fig. 2a,b. Pipiograptus hesperus Whittington. Viola Springs Limestone, Oklahoma. a: young specimen, reverse view. U.C.W. Stub G555. Neg. 83/20/17. b: more mature specimen, obverse view. U.C.W. Stub G416. Neg. 81/36/36. 

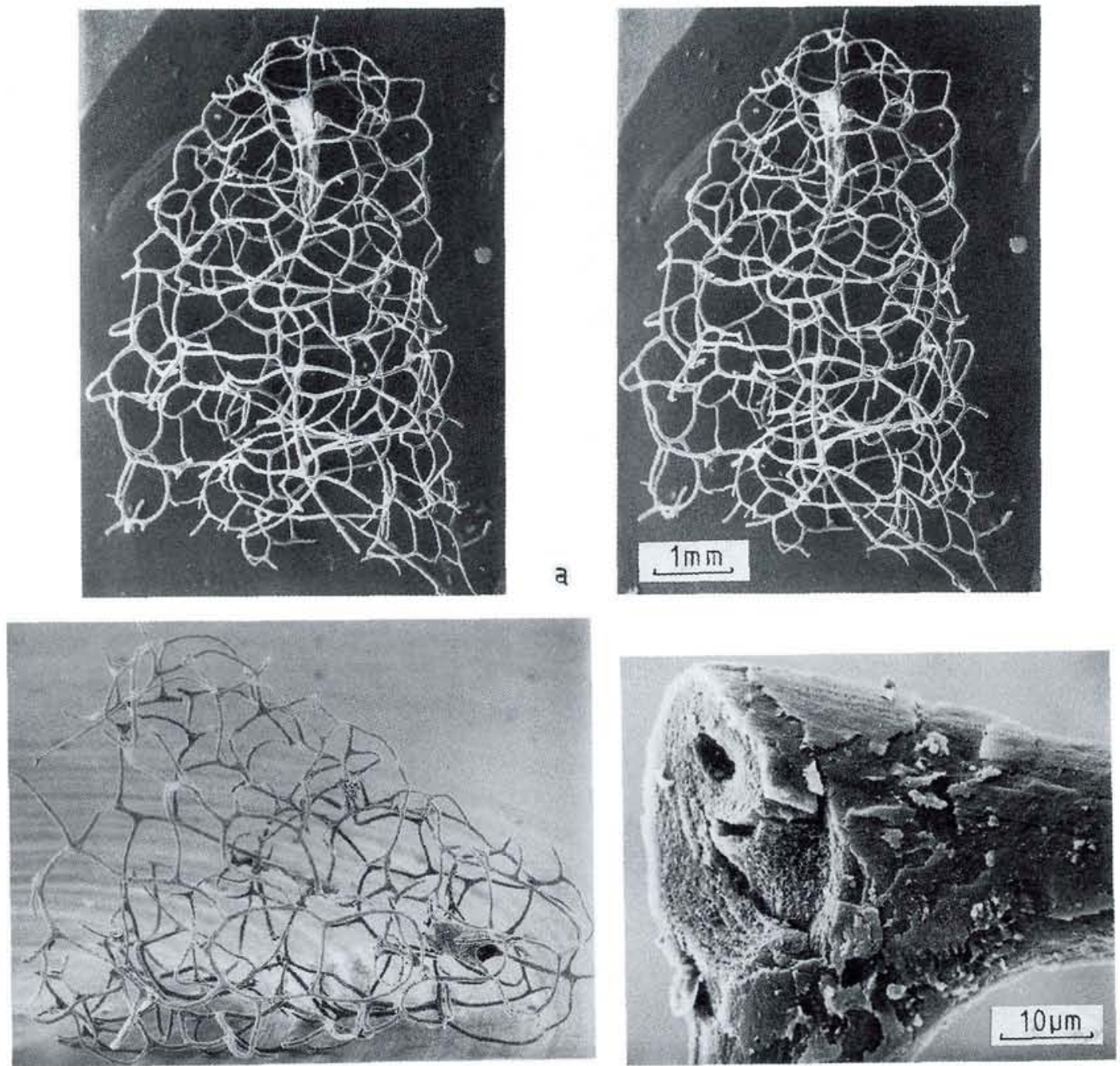

b

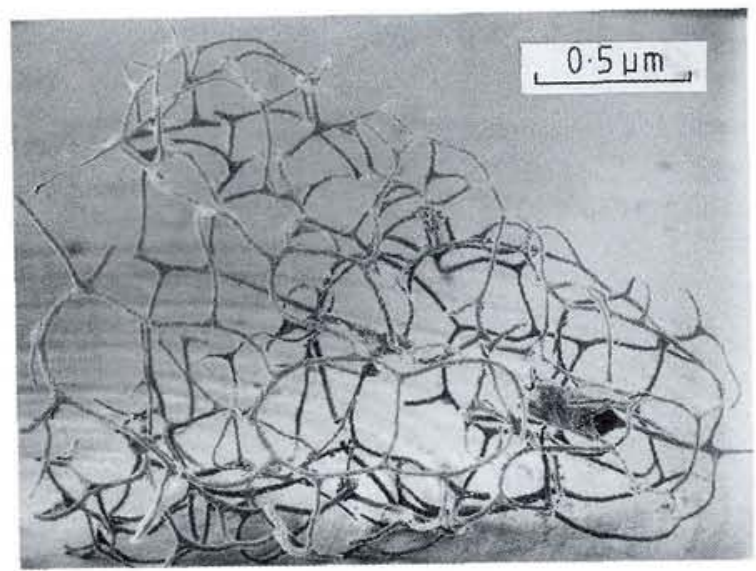

C

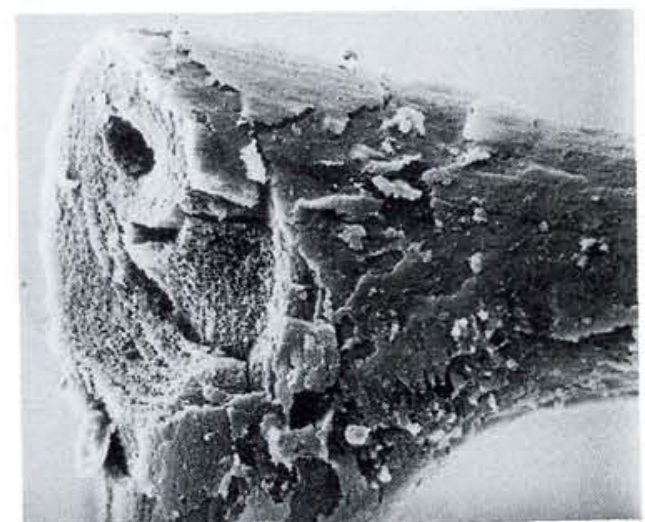


Fig. 4. Phormograptus sooneri Whittington. Viola Springs Lst., Oklahoma. a, b: Stereopairs of mature rhabdosomes. c: Stereopair of lacinia forking (compare with fig. 5). a: U.C.W. Stub G563, Negs. 83/24/19-20. b: U.C.W. Stub G524, Negs. 83/31/5-6. c: U.C.W. Stub G524, Negs. 83/36/21-22.

have provided increased opportunity for gaseous exchange and the circulation of metabolites.

In the second laciniate retiolitid graptoloid of this series, Phormograptus sooneri (Whittington 1955), only the sicula and most proximal part (hood) of th $1^{1}$ are strengthened by cortical bandages and preserved (fig. 1g; fig. 4). Elsewhere the thecal walls have only been bandaged along narrow tracks and so are only preserved as a framework of lists with traces of the incremental walls along their edges. Even the thecal framework is more sparse than in $P$. hesperus. Thus th $1^{1}$ and $1^{2}$, beyond the proximal hood, are each represented only by a ventral list and apertural hoop, while subsequent thecae are represented by an obverse and a reverse dorsal or zig-zag list connected to the apertural and abapertural lists.

The lacinia, like that in $P$. hesperus, arises from the strongly corticized parts of the thecal framework: from the apertural spines of sicula and thecae, from the sicula wall and hood of th $1^{1}$, and from extrathecal extensions from the paired transverse struts connecting the virgula with the dorsal, zig-zag lists.

The lacinial network is more complex than that of $P$. hesperus. Thus there are latitudinal lacinial connections in between successive thecae on the ventral faces of the rhabdosome, and the extrathecal extensions of the paired transverse struts branch in a dendroid or tree-like manner (fig. 5) to support a network in three dimensions (fig. 1h). Again we are reminded of the three dimensional networks of the Demospongiae and can only suggest a similar mode of secretion within the intercellular matrix of the mantle mesenchyme.

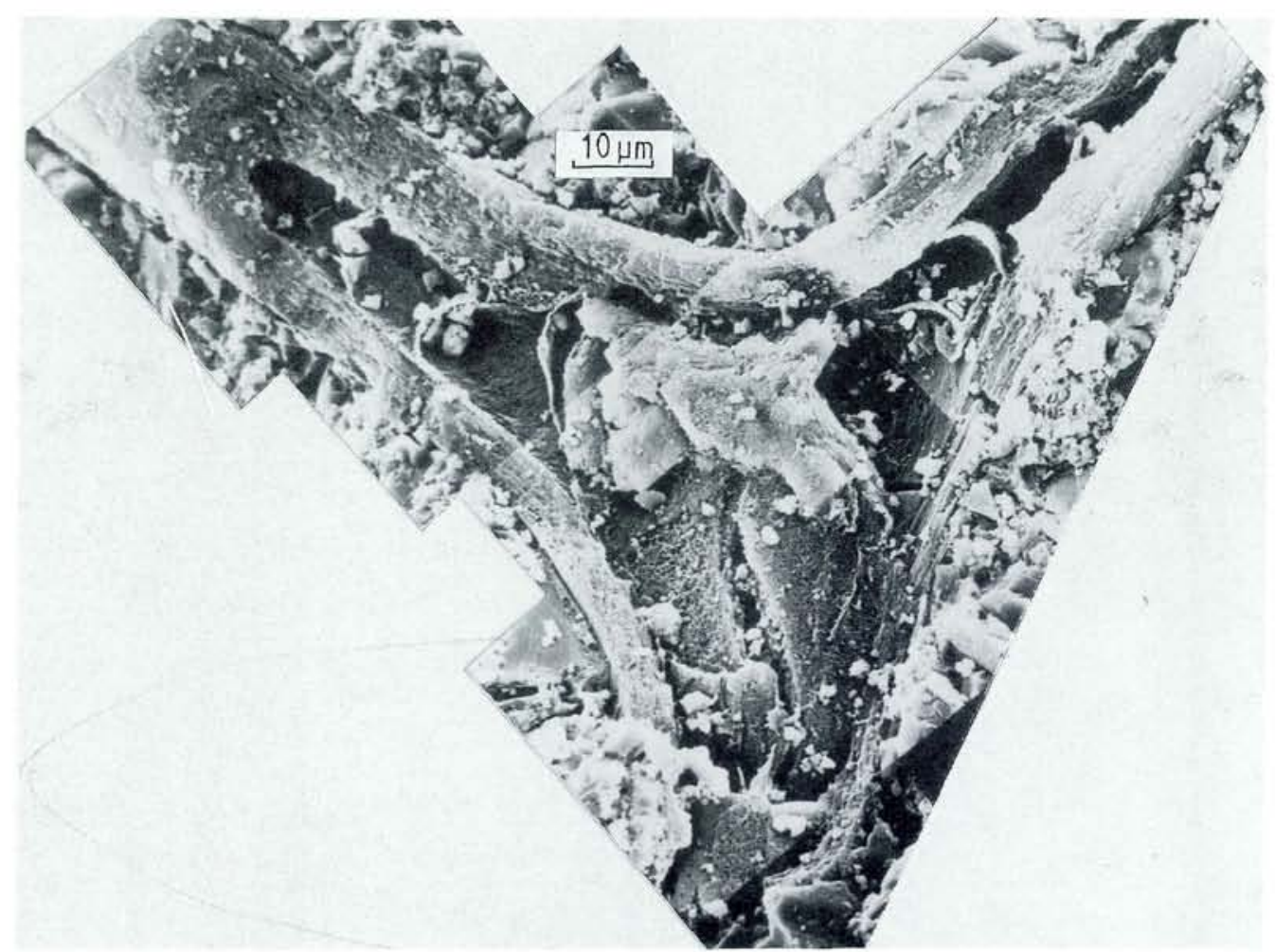

Fig. 5. Fractured forking spine of Phormograptus in which hollow conical increments are bounded by lamellae of packed criss-cross fibrils and overlain by longitudinal bandages. (These incremental cores have been omitted from fig. If). U.C.W. Stub G368, Negs. $81 / 23 / 29-35$. 
In Phormograptus sooneri it seems obvious, from the appearance of the colony, that all the thecae were dependent for their support and protection on the lacinial network within the mantle, the lacinia being supported axially by the sicula and distally widening virgula via the transverse struts arising from them. It would seem that here, as in $P$. hesperus, the reduction in corticization of the thecal walls must have proceeded pari passu with the development of the lacinial support.

So again, in Phormograptus, we find the jagged outlines of the thecate rhabdosome surrounded by a smoothly ovoid envelope covered by ciliated mantle epidermis. Ideally constructed to avoid entanglement, this again would have been able to maintain a smooth flow of oxygenand food-bearing water over itself, the food particles being diverted into the ciliated funnels leading to the sicular and thecal apertures.

Again, if the inflated mesenchyme had contained low density inclusions it could have contributed directly to the buoyancy of the colony, as well as indirectly by permitting economies in corticization of the thecae. The distally thickening virgula (fig. 4a) would have balanced the heavy periderm of the sicula and th $1^{1}$ hood, helping to keep the distal end of the colony down during life. Here, at the trailing end, the extension of the delicate thecal framework and lacinial lists would have proceeded in the favourable environment of the slipstream of the ciliary flow.

The third laciniate retiolitid of this morphological series, Archiretiolites regimontanus, we have only been able to study from Eisenack's excellent drawings and descriptions (Eisenack 1935). These show that, again, only the sicula and hood of th $1^{1}$ were corticized, the remainder of th $1^{1}$ and $1^{2}$ being represented by a highly asymmetrical framework of lists (fig. 1i). Again the lacinia appears to have arisen as spines from the sicula and thecal framework, and from transverse struts arising from the virgula.

In the young colony figured by Eisenack, the lacinial spines have formed a cylindrical network extending from th $1^{1}$ towards th $1^{2}$, superimposing a sort of symmetry upon the irregular rhabdosome and supporting the first thecae. As in Phormograptus sooneri, the virgula and the transverse paired structs arising from it form the axial support of the mature lacinia which in turn seems to have supported and protected the mainly uncorticized thecae.

In summary, it may be concluded that in all these Ordovician laciniate retiolitids there has evolved a device for modifying the ciliated epidermal surface so as to produce a smooth ciliary flow over it, with diversion of food into ciliated funnels leading to the zooids. Stretched over an inflated mesenchyme it would have increased the possibilities for gaseous exchange, while the mesenchyme itself would have facilitated metabolic exchange and could have contributed both directly and indirectly to the buoyancy of the colony, enabling it to live in the higher layers of the photic zone. Here the smooth network would have both supported and protected the underlying thecae and obviated any risk of entanglement.

2. A morphological series of Silurian ancorabearing graptoloids. (fig. 6).

Since the structure and probable function of the ancora and ancora-sleeve have already been briefly outlined (Bates \& Kirk 1984) we will concentrate here on their likely mode of secretion, and the part played by the mantle, in association with the ancora, in feeding and automobility.

Three non-retiolitid taxa were described, differing in the form of their ancorae but sharing the characterisitic of remarkably early construction, the ancorae being essentially completed before the onset of budding. In Petalograptus (fig. 6b) the four branches of the ancora already extended from the tip of a long slender virgella when the metasicula had only incrementally extended about half its length along it (fig. 6a). In Orthograptus obuti(?) (fig. 6c) and in $O$. insectiformis(?) (fig. 6d) a complex double spiral "umbrella" supported by four similar ancora branches was again essentially completed before budding began.

In order to explain the secretion of such a large peridermal structure while the siculozooid was still adding metasicular increments to its own peridermal wall, it seems necessary to suppose that the ancora was adding to the metabolic resources of the organism at least as much as was being subtracted for its construction.

In terms of a petrobranch-like organism, painting on the peridermal increments and bandages 

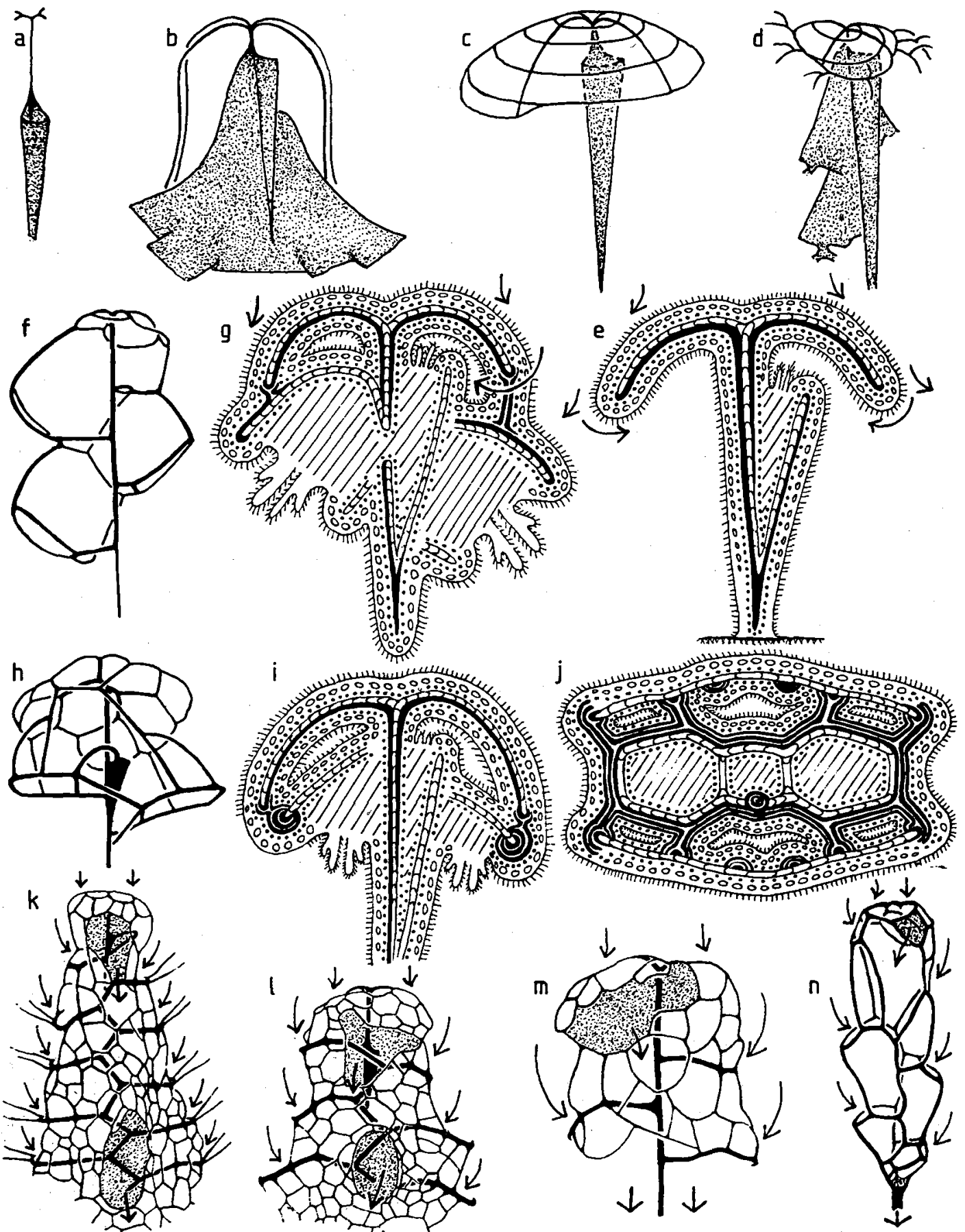

Fig. 6. Ancora-bearing Silurian graptoloids. (see text for explanation). 

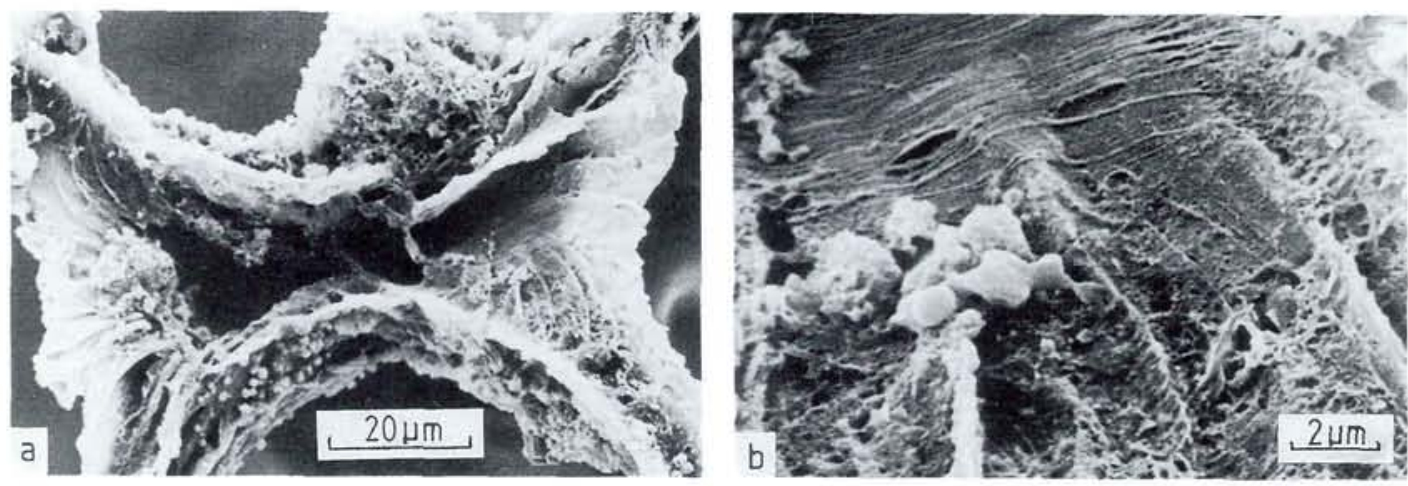

Fig. 7. Orthograptus insectiformis(?), U. Llandovery, Kalholn, Sweden. a: Central part of ancora (looking towards the sicula), showing the origin of the double spiral series of umbrella increments. U.C.W. Stub G476, Neg. 82/34/35, b: Close-up of a., showing thin bandaging over the increments on the convex surface of the ancora umbrella. Neg. 82/23/30.

with its preoral lobe, this seems impossible. But on the supposition that the periderm was secreted by epithelium covering the zooid and extending from it as the mantle lining, it becomes possible to envisage the secretion of a long slender virgella as ventral extensions of the two series of earliest overlapping metasicular increments, and strengthened by the secretion of bandages along its length. Even at this early stage of development, the ciliated epidermis of the mantle enveloping the extended virgella could have been augmenting the food-bearing current flowing to the siculozooid. Upon attainment of the full virgellar length, the secretion of the two series of increments diverged so that two overlapping spiral series of increments began to extend from the virgella tip in a plane almost at right angles to the virgellar axis. These spirally added increments formed the ancora "umbrella" which was supported by cortical bandages secreted on to its concave side (fig. 6e). These bandages were restricted to four tracks and are familiar as the four ancora branches. They were secreted in continuity with the bandages forming the outer cortical layers of the thickened virgella. Traces of the double spiral series of increments are preserved only over the outer faces of the four cortical branches. Where one series oversteps the other series a spiral thickening is formed and this may still be preserved between as well as overlying the branches, especially in $O$. obuti(?) and $O$. insectiformis(?) (figs. 6c,d). Bandaging over the convex surface of the incremental umbrella is also preserved, but much more rarely, since it was much thinner. However, it can be seen over the increments at the centre of the umbrella (figs. $7 \mathrm{a}, \mathrm{b}$ ), and again at the rim (as in fig. 8), indicating that the spiral increments were thin, and that the secretory epithelium once enveloped the entire structure.

According to the theory of automobility it seems likely that the graptoloid larva became attached to the sea floor as in the dendroid ancestors, and that the young colony developed as a benthonic organism perhaps until the first two thecae began to bend round towards the sicular apex. Detachment could then have occurred followed by an automobile existence in the plankton.

If this had been the case in the ancora-bearing graptoloids it is possible to envisage the ancora as

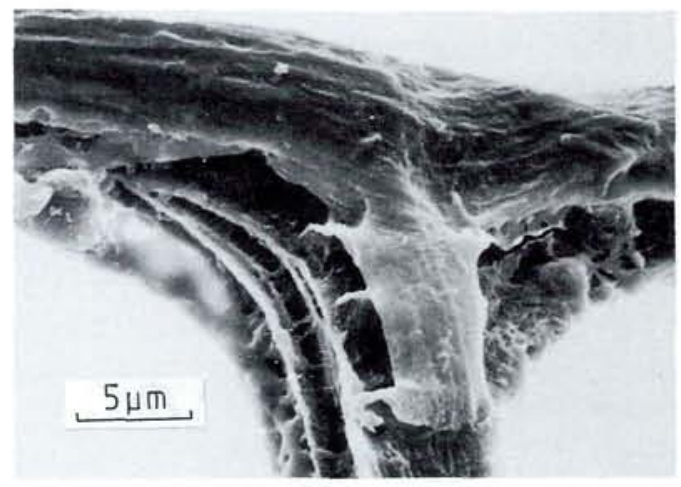

Fig. 8. Retiolites sp., U. Llandovery, Osmundberget, Sweden. Rim of ancora showing three umbrella increments preserved between the thick bandages of an ancora branch and thin overlying bandages. U.C.W. Stub G734. Neg. 85/1/12. 

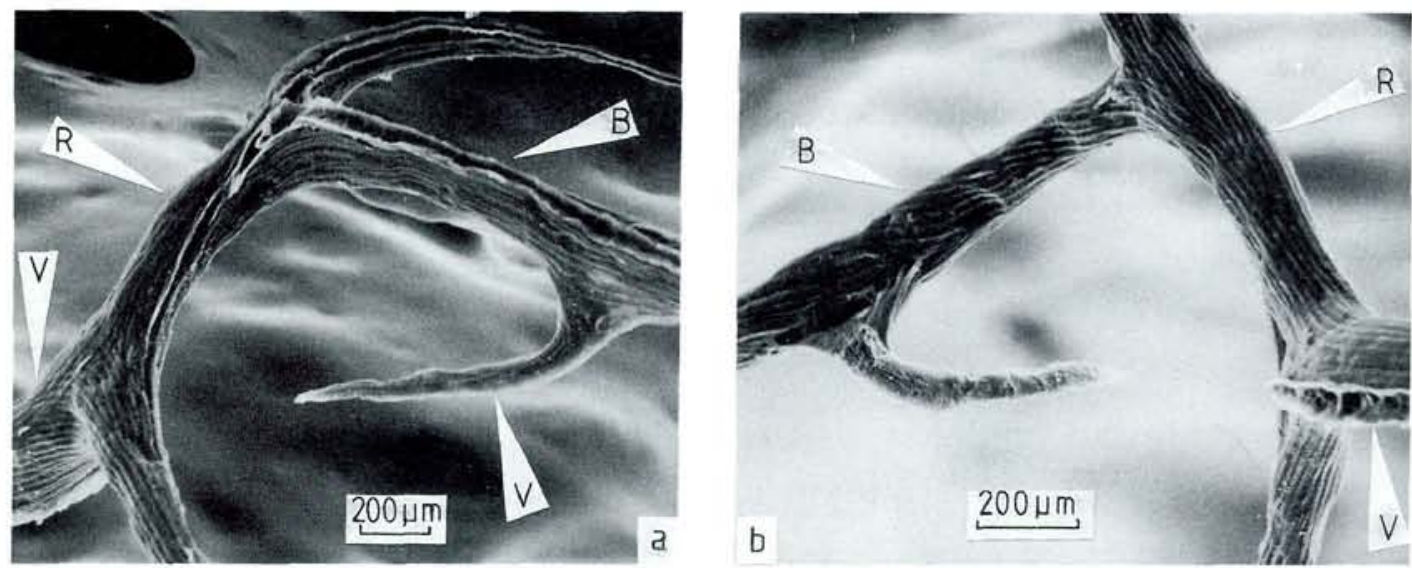

Fig. 9. Retiolites sp., U. Llandovery, Osmundberget. Attachment of the ventral strut (V) of theca $1^{1}$ to the ancora rim (R), and to ancora branch (B), a. convex side, b. concave side of umbrella. U.C.W. Stub G735, Negs. 84/67/25, 33.

a device for extending the ciliated mantle upwards for the purpose of increasing the flow of food-bearing water to the tiny benthonic siculozooid (fig. 6e). The ancora umbrella overhanging the sicula is reminiscent of the medusa-bell of Aurelia, and we suggest that the cilia over its convex surface may have similarly directed a flow of water onto and over it, the food particles perhaps being caught in mucus under its rim and then swept by cilia over the concave surface to the siculozooid. The efferent current may be supposed to have flowed away from the rim. On this supposition the ancora-extension could have contributed more to the metabolic resources of the organism than was abstracted from them by the construction of its proteinaceous support, and indeed this seems to be an essential requirement for its evolution. After the liberation of the colony at an early stage of thecal development, the same ciliary action would have contributed to the feeding-rise and to automobility. The umbrella would also have protected the siculozooid from the direct impact of microorganisms and debris, both in the benthonic stage and again in the planktonic stage where it would have faced the ciliary flow at the leading end of the colony.

In the first retiolitid graptolite of the morphological series described in 1984, Retiolites sp. Osmundberget, a small ancora umbrella with traces of a double spiral thickening was intimately connected with the first two thecae (fig. 6f). In this taxon the incremental walls of sicula and thecae have only been thickened by cortical bandages along certain narrow tracks, and so are only preserved as a framework of dorsal, ventral and apertural lists connected to the prosicular rim and virgula.

The ventral list of th $1^{1}$, with cortical bandages secreted onto it from the outside, is connected to the rim of the ancora umbrella, and more rarely to one of the four ancora branches secreted on to the concave side of the umbrella (figs. $6 \mathrm{~g}, 9$ ). The bandages which extend from umbrella to theca consequently invert as they make the connection. This is readily explicable if we suppose that the mantle covering the ventral wall of th $1^{1}$ and the mantle lining the concave side of the umbrella became confluent, allowing the secretory epithelia to unite and secrete as a continuum.

The ventral list of th $1^{2}$ is more distant from the ancora rim, and a strut or list, round in transverse section and with no evidence of previous attachment to a membrane, connects the two structures (fig. 10). It seems necessary to suppose that here also the mantle enveloping the ancora rim and the mantle covering th $1^{2}$ became locally confluent, allowing epithelial cells to arrange themselves to form a tube in which the seamless strut could be secreted. Again there is a kind of inversion of the bandages covering the ventral list of th $1^{2}$ as they extend along the strut and then spread over the rim of the umbrella.

In this taxon we again postulate a primary feeding function and a secondary protective function for the ancora umbrella. But in this taxon it also seems to have contributed to the support of 

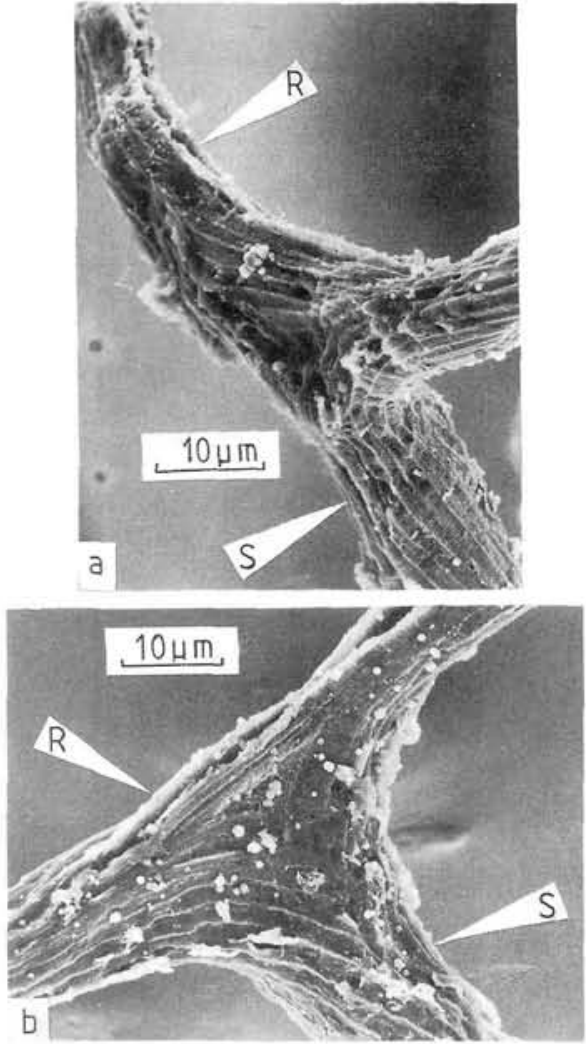

Fig. 10. Retiolites sp., U. Llandovery, Osmundberget. Two views of strut (S) connecting ventral list of theca $1^{2}$ to the ancora rim (R), a. convex side, b. concave side of umbrella. U.C.W. Stub G284, Negs. 80/10/2-3.

the first thecae, the reduced corticization of their walls being perhaps a corollary of that support.

Formation of connections between the mantle lining the ancora umbrella and the mantle covering the ventral walls of th $1^{1}$ and th $1^{2}$ would have left sea-filled spaces between them (fig. $6 \mathrm{~g}$ ). It has to be supposed that currents created by the ciliated epidermis of the mantle would have carried food particles from the umbrella rim through these spaces to the siculozooid. Whether this zooid continued to have a ciliated lophophore as conventionally imagined, or whether that structure was replaced by the ciliated, sea-filled canal system is unknown.

In the remaining retiolitid taxa of our 1984 series the ancora membrane extended distally as a sleeve enclosing the thecae. Traces of the peridermal increments of the ancora membrane are only rarely preserved, but cortical bandaging has extended beyond the initial four-lobed umbrella rim and formed a network of lists clearly secreted on to the inside of the ancora membrane in continuity with the bandaging over the outside of the virgella. (In some beautiful examples of Pseudoretiolites $\mathrm{cf}$. decurtatus illustrated by Lenz \& Melchin (this volume) the meshes of the initial part (corona) of the ancora sleeve also have a double spiral arrangement which perhaps reflects the double spiral series of increments forming the overlying membrane).

The extension of the ancora umbrella to form a sleeve allowed contact to be made with the apertural lists of successive thecae. The nature of the peridermal connections is seen most clearly in Retiolites geinitzianus (figs. $6 \mathrm{~m}, \mathrm{i}$ ) where both thecal framework and ancora network have been heavily bandaged (Bates \& Kirk 1978). In this taxon the apertural lists preserve traces of fusellar increments in proximal-facing grooves, but these are heavily overlaid by bandages, the earliest being adjacent to the increments in the cores, the latest covering the outside of the lists. The ancora sleeve is supported by cortical bandages secreted from the inside. They describe a reticulate pattern and constitute the so-called reticulum, with their earliest bandages adjacent to the sleeve membrane, and successively later bandages being added further from it.

At the junction between reticulum and apertural list, the earliest and outermost bandages of the reticulum are continuous with early bandages in the core of the apertural list, while the latest and innermost bandages of the reticulum are clearly continuous with the outermost bandages wrapping the apertural list (transverse section (fig. $6 \mathrm{j}$ ). This results in an interesting "plug-hole" arrangement, as the earliest bandages of the reticulum appear to plunge down a tube of later bandages into the core of the apertural list (fig. 11).

This superficially complex arrangement follows simply from the mode of secretion within an all enveloping mantle. It is necessary to suppose that here, as in Retiolites sp., Osmundberget, the mantle enveloping the ancora sleeve and the mantle enveloping the thecal aperture had become locally confluent allowing fusion of their secretory epithelia. Again secretion from the inside in the case of the cortical bandages of the ancora, and secretion from the outside in the case of the 

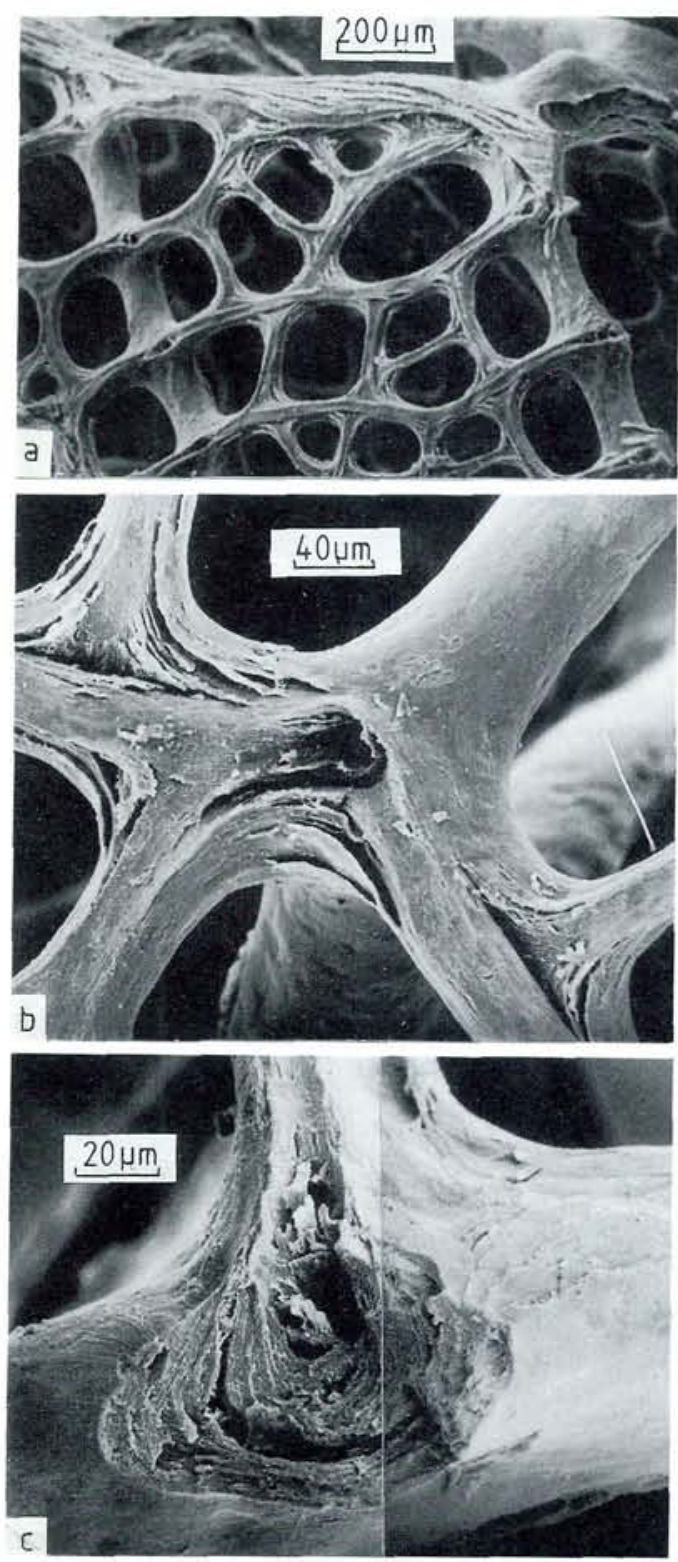

Fig. 11. Retiolites geinizianus, U. Llandovery, Cornwallis Island. Canada. U.C.W. Stub 95, a: Outer face of reticulum, making "plughole". junctions with two apertural lists. Neg. $76 / 2 / 34$. b. c: Close-up views of "plugholes". The earliest and outermost cortical bandages of the reticulum plunge into the "plughole" to make contact with the early inner cortical layers of the apertural list: the hole was probably partially occupied by criss-cross fibrils. Negs. 76/28/25, 77/44/16-17.

thecal bandages, necessitated an inversion at the connection which resulted in the "plug-hole" arrangement.

As in Retiolites sp. Osmundberget, the local- ised junctions between the mantles of ancora and thecae would have left seafilled spaces between the ciliated mantle epidermis lining the ancora sleeve and the ciliated epidermis covering the thecal mantle. The resulting ciliated canal system has left its traces on the reticulum. Certain meshes of the ancora sleeve are thickened and clearly surround orifices which could have led into the canal system (fig. $6 \mathrm{k}, 1, \mathrm{~m}, \mathrm{n}$, stippled areas).

At the proximal end of the rhabdosome there seem to be always four such orifices proximal to the first apertural lists. Two, on the ventral faces, open proximal to the apertural lists of th $1^{1}$ and $1^{2}$, and the two others open on the obverse and reverse faces of the rhabdosome. It is suggested that the ventral orifices may have served as inlets for the currents carrying food to the siculozooid, while the reverse and obverse orifices may have served as outlets for the efferent currents from it.

More distally there appears to have been a ventral orifice adjacent to each apertural list, and, in some retiolitids, a succession of more distal obverse and reverse orifices (the stomata) is also developed. In Stomatograptus these are somewhat protruding with thickened rims (fig. 61), while in Pseudoplegmatograptus (as figured by Lenz \& Melchin this volume; but referred to as Sinostomatograptus by Bates \& Kirk 1984) the rims of the large and strongly protuberant stomata are unthickened (fig. $6 \mathrm{k}$ ). We suggest that the ciliary currents entering the ancora sleeve adjacent to the thecal apertures and supplying particulate food to the zooids, passed on through the ciliated sea-filled canals, and left the rhabdosome at the protuberant stomata, ensuring a good separation of the spent water from the afferent currents,

The large gap between the thecal framework and the ancora sleeve at these stomata might seem to imply a mantle with greatly inflated mesenchyme as suggested for the Ordovician retiolitids, but in the Silurian taxa this was not necessarily the case because much of the space would have been occupied by sea-filled ciliated canals. These would have been weightless and yet could have contributed greatly to the ciliary flow to and from the rhabdosome, augmenting or even replacing the conventional zooidal lophophores.

However there is evidence that, at least in Pseudoplegmatograptus, there was considerable 
inflation of the ancora sleeve periderm onto which the reticulum was secreted from below. Two specimens preserve traces of an additional outer reticulum which was secreted from the outside on to this membrane (fig. 12). The lists of this outer reticulum have their earliest bandages facing inwards. They extend from one unthickened stoma to the adjacent stoma proximal or distal to it, and also from the ventral orifices to the obverse and reverse stomata. Apart from the gap between the inner and outer reticula this intervening membrane has left no trace. We can only suppose that its increments were very tenuous and unbandaged.

Apart from Stomatograptus and Pseudoplegmatograptus, the remaining retiolitids of this morphological series had only the two proximal, obverse and reverse, efferent orifices, and we conclude that in these taxa, after diversion of the food particles to the zooids (perhaps in mucus), the main efferent flow from the thecal apertures would have passed under the ancora sleeve and left by the open, growing end of the rhabdosome where the ciliated canals would have communicated directly with the sea (fig. $6 \mathrm{~m}$ ).

In these taxa we also find increasing importance in the development of the reticulum secreted onto the ancora sleeve membrane from the outside. The membrane in these cases was comparatively thin with occasional traces of incremental closures. Thus in Paraplectograptus (Lenz \& Melchin, this volume; Retiolites sp., Cornwallis Island, Bates \& Kirk 1984) all the proximal and most of the distal parts of the reticulum were secreted from the inside, while parts of the distal reticulum have meshes secreted from the outside too. In Gothograptus nassa the proximal part of the ancora sleeve (the corona) has a heavily corticized reticulum secreted from the inside, with the conventional four initial

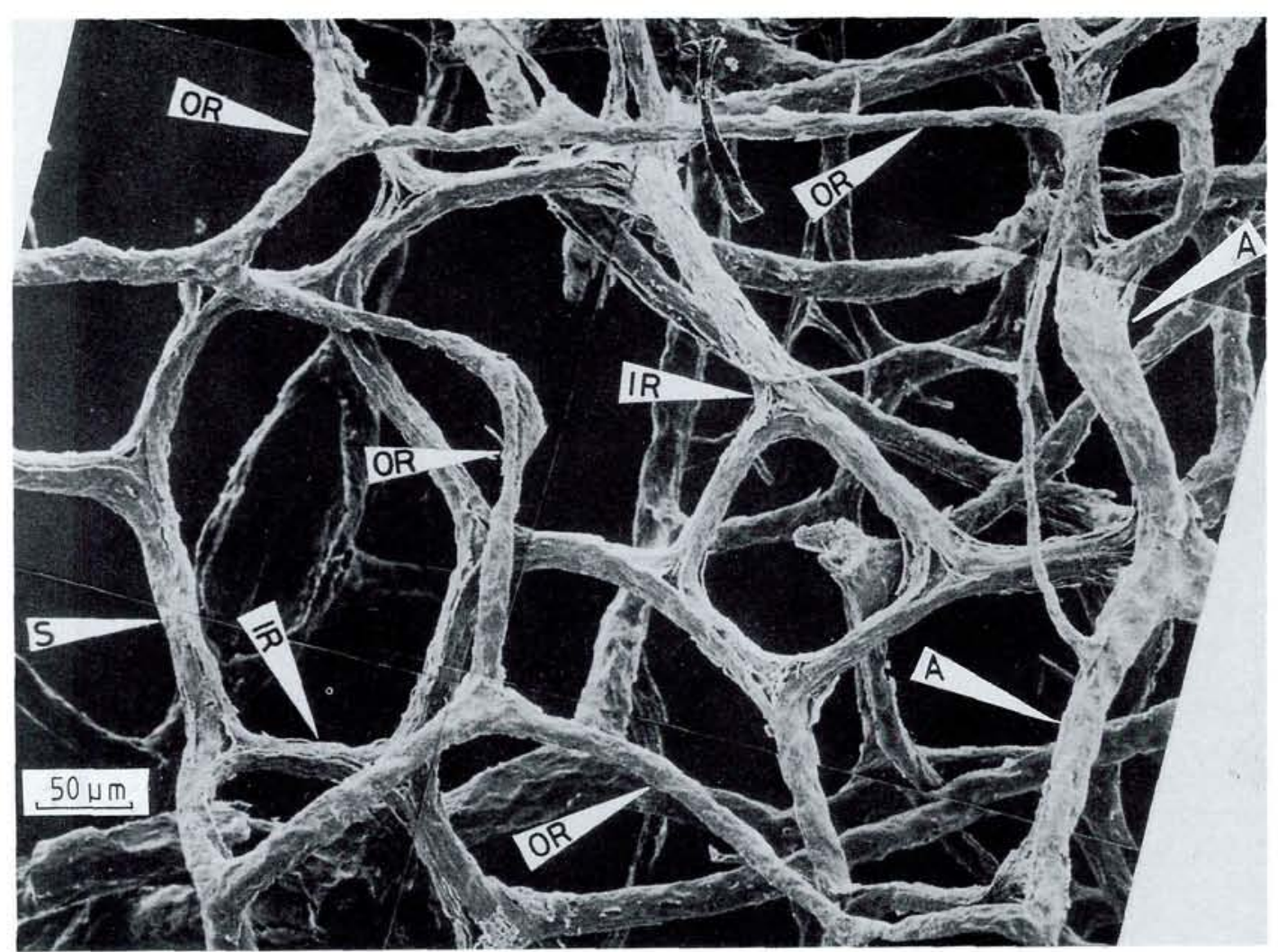

Fig. 12. Pseudoplegmatograptus sp., U. Llandovery, Osmundberget. Portion of rhabdosome in which a downward facing outer reticulum (OR), and an upward facing inner reticulum (IR) extend from an orifice or stoma (S) on the left to the edge (A) of the ancor sleeve bordering a ventral orifice on the right. The intervening membrane of the ancora sleeve has left no trace. U.C.W. Stub G288. Negs. 80/47/33-36. 80/48/1-2. 
branches bandaged in continuity with the sicular rim. Outside this, and separated from it by a gap representing the ancora incremental membrane, is a reticulum with a quite different pattern of bandages and secreted from the outside (Bates \& Kirk 1986: Pl. 5). The inner reticulum dies out distal to the four proximal orifices, and it then becomes almost impossible to distinguish between the distal reticulum secreted from the outside and the similarly thickened thecal lists.

In Holoretiolites simplex (fig. 6n) the reticulum of the corona was secreted only from the inside, and has the conventional four initial branches. As in $G$. nassa however, there is a change to a reticulum secreted from the outside at the level of the four proximal orifices. In $H$. simplex the difficulty of distinguishing the lists supporting the ancora sleeve from the thecal framework is increased by the formal pattern of diagonal, vertical and horizontal lists adopted by the reticulum.

In the holoretiolitids, and also in some gothograptids the rhabdosome has become finite and the reticulum extends some way distal to the last thecal apertures, becoming slightly modified in the arrangement of its lists as it passes into the narrow tubular framework of the appendix (fig. 13).

The difficulty of distinguishing thecal framework from the lists of the ancora sleeve, when these have been secreted from the outside, complicates the problem of interpreting the nature and function of the appendix found in these taxa.

If this part of the reticulum represents the narrowed distal portion of the ancora sleeve extending beyond the finite thecate part of the

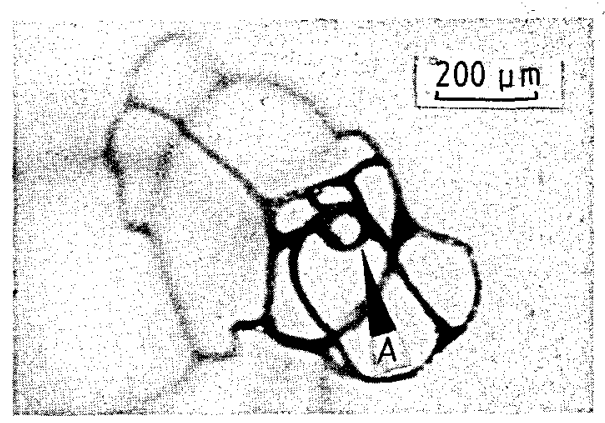

Fig. 13. Holoretiolites simplex Eisenack, lower Ludlow, Grunlichgraues Graptolithengestein (specimen loaned by Dr. H. Jaeger). Light micrograph, looking proximally through the appendix (A), which is circular in this view. Neg. 85/28/17. rhabdosome, the outflow of spent water from it would then have been most advantageously separated from the afferent flow to the zooids and could also have contributed most effectively to the feeding rise (Bates \& Kirk 1984). If, on the other hand, the reticulum of the appendix covered an extension of the common canal, it may only have served as a modified organ of excretion from the zooids, the main efferent flow passing over the outside of its mantle cover and carrying away the waste products from its terminal orifice. The small internal diameter of the appendix in $H$. simplex, about $75 \mu \mathrm{m}$, seems to favour the second hypothesis, especially when it is remembered that it must have been lined as well as covered by living tissue.

However on either, or on any other interpretation, the perfected stream-lining of the finite appendiculate rhabdosome would seem indicative of active vertical movememt, the strong bulbous corona meeting head-on the resistance of the water on the feeding rise, the delicate growing ends of the lists being extended distally in the slipstream of the ciliary flow, where the resistance would have been minimal. With completion of the structure the appendix became strongly thickened, but not closed, perhaps to serve as a balance to the weight of the corona.

The continued existence of ancora-bearing retiolitids long after the disappearance of most other biserial graptoloids seems to have been the consequence of their unique construction. The extension of the ancora sleeve not only perfected the separation of the efferent from the afferent currents, solving a problem which probably afflicted all graptoloids after their abandonment of the cone-shaped rhabdosome of Dictyonema, but it must also have greatly increased the ciliary flow. The extension of the ancora sleeve would have roughly trebled the surface area of the ciliated mantle and with it the supply of food and oxygen and the area for gaseous exchange. The weightless ciliate canals beneath the reticulum would also have constituted a shock-absorbing protective jacket for the unbandaged thecae, while the reticulum itself took over their support.

The sparse reticulum of $H$. simplex formed of a minimal number of delicate longitudinal, diagonal and horizontal lists, seems to have attained near perfection in the economical resistance to distortion by the ciliary flow. Even the virgula is 
unpreserved and the virgella reduced to a vestige at the origin of the four initial ancora branches. The knobs "ornamenting" the outer face of the lists may have helped to prevent "décollement" between the collagenous bandages and the epithelium which covered and secreted them.

Apart from its ciliated epidermis the all enveloping mantle seems to have been as unprotected as in all other graptolites. The rarity of abnormalities in the bandaging of the outer surfaces of graptolite rhabdosomes suggests some invisible protection in addition to the continual sweeping action of the cilia. The soft tissues were perhaps poisonous with warning coloration combining with the resilient, almost indestructible and probably very indigestible periderm in repelling predation over their long evolutionary history.

\section{Dansk sammendrag}

Ordoviciske biseriale graptoliter med veludviklede torne og former med lacinia (et netformet skelet understøttet af torne uden på det egentlige koloniskelet) er blevet beskrevet. Dannelse og anastomose af tornene og lacinia er fors $\emptyset \mathrm{gt}$ forklaret som en sekretion af celler $i$ et ydre bløddelslag, "mesenchym «, som omgav det egentlige graptolitskelet, og væksten er antaget at foregå på samme måde som for dannelsen af fibre $i$ hornspongier.

For Pipiograptus hisperus og Phormograptus sooneri, begge med lacinia, er det foreslået, at et bløddelslag, som indeholdt lacinia, udadtil var omgivet af en epidermis med cilier, hvis funktion var at danne en vandstrøm med fødepartikler hen mod zooiderne $i$ thekerne, langs specielle cilierede kanaler. I begge graptolitarter er thekevæggen stort set uden et ydre kortikallag med en båndet struktur, og både st $\emptyset$ tte og beskyttelse af zooiderne er foreslàet overtaget af lacinia omgivet af denne kappe af bløddelsvæv.

Nogle biseriale graptoliter danner en ancora, en ankerlignende udvakst fra virgella i de tidlige vækststadier af graptolitkolonien. Ancora kan udvikle sig til en paraply-lignende struktur bestående af et netformet skelet, placeret rundt om sikula og de første theker. Dannelsen af ancora hos nogle ikke retiolitide Silure graptoliter er her forklaret ved en vækst under en udstrakt bløddelskappe, som omgav virgella. Udviklingen af ancora på et tidligt stadium af sikulas vækst er her forklaret ved, at ancora havde funktion som fødeopsamlende organ, medens den juvenile koloni stadig var fastheftet til havbunden.

I de Silure retiolitider strakte den paraplylignende ancorastruktur sig bagud over den thekate del af rhabdosomet, og det er foreslået, at denne struktur her understøttede de første theker, som stort set mangler det båndede kortikallag i deres skelet. Omgivet af en kappe med en cilieret epidermis kunne ancora have været medvirkende til at danne vandstrømme, bl.a. udstrømmende vand fra distaldelen af rhabdosomet, i mere specialiserede tilfælde hos nogle retiolitider fra særlige åbninger i skelettet, stomata.

Vandstrømmene over en cilieret kappe antoges at have bidraget som hjælp ved graptoliternes opstigning i vandmasserne. Det er endvidere foreslået, at det ydre bløddelsvæv kunne medvirke ved åndingsprocesser, samt at der i vævet var indesluttet stoffer (gasarter eller fedt?) som kunne forbedre koloniens opdrift.

\section{References}

Bates, D. E. B. and Kirk, N. H. 1978: Contrasting modes of construction of retiolite type rhabdosomes. Acta Palaeont. Pol., 23, 427-448.

Bates, D. E. B. and Kirk, N.H. 1984: Autecology of Silurian graptoloids. In: Bassett, M. G. (ed) Autecology of Silurian Organisms, Spec. Pap. in Palaeont., 32, 121-139.

Bates, D.E.B. and Kirk, N.H. 1985: The fine structure of graptolite periderm. In: A. Bairati \& R. Garrone (eds.) Biology of invertebrate and lower vertebrate collagens, 389396. New York \& London: Plenum Publishing Corporation. (Proceedings of NATO Advanced Research Workshop, Como, Italy 1984).

Bates, D. E. B. and Kirk, N. H. 1986: The mode of secretion of graptolite periderm in normal and retiolite graptolites. In: C. P. Hughes \& R. B. Rickards (eds.) Palaeoecology and Biostratigraphy of Graptolites, 221-236. Geological Society of London Special Publication 20: Blackwells Scientific Publications Oxford. (Proc. 2nd Int. Graptolite Conf., Cambridge 1981).

Bulman, O.M. B 1932: On the graptolites prepared by Holm. Arkiv f. Zoologie, 24A, 1-46.

Crowther, P. R. 1981: The fine structure of graptolite periderm. Spec. Pap. in Palaeont., 26, 1-119.

Eisenack. A. 1935: Neue Graptolithen aus Geschieben baltischen Silurs. Palaont. Zeischr., 17, 73-90.

Garrone, R. 1978: Phylogenesis of connective tissue. Morphological aspects and biosynthesis of sponge intercellular matrix. Frontiers of Matrix Biology, 5, 1-248.

Kirk, N. H. 1969: Some thoughts on the ecology, mode of life and evolution of the Graptolithina. Proc. Geol. Soc. Lond., 1659, 273-292.

Kirk, N.H. 1972: Some thoughts on the construction of the rhabdosome in the Graptolithina, with special reference to 
extrathecal tissue and it bearing on the theory of automobility. Publ. Dept. Geol. Univ. Coll. Wales, Aberystwyth, $1,1-21$.

Kirk, N.H. 1974: More thoughts on the construction of the rhabdosome in the Dendroidea, in the light of the ultrastructure of the Dendroidea and of Mastigograptus. Publ. Dept. Geol. Univ. Coll. Wales, Aberystwyth, 6, 1-11.

Kirk, N. H. 1975: More thoughts on the construction and functioning of the rhabdosome in the Graptoloidea in the light of their ultrastructure. Publ. Geol. Dept. Univ. Coll. Wales, Aberystwyth, 7, 1-21.

Lenz, A.C. \& Melchin, M. J. 1987: Silurian retiolitids from the Cape Philips Formation, Arctic Islands, Canada. Bull. geol. Soc. Denmark, vol. 35, pp. 161-170.
Towe, K. M. \& Urbanek, A. 1972: Collagen-like structure in Ordovician graptolite periderm. Nature, London, 237, 443-5.

Urbanek, A., Koren, T. N. and Mierzejewski, P. 1982: The fine structure of the virgular apparatus in Cystograptus vesiculosus. Lethaia, 15, 207-228.

Vacelet, J. 1971: Ultrastructure et formation des fibres de spongine d'éponges cornèes Verongia. J. Microscopie, 10, 13-32.

Whittington, H. B. 1955: Additional new Ordovician graptolites and a chitinozoan from Oklahoma. J. Paleont., 29, 837-851. 